\title{
Sexual reproduction by the Caribbean reef corals Montastrea annularis and M. cavernosa
}

\author{
Alina M. Szmant \\ Rosenstiel School of Marine and Atmospheric Science, University of Miami, 4600 Rickenbacker Causeway, Miami,
} Florida 33149, USA

\begin{abstract}
Reproductive characteristics of Montastrea annularis and $M$. cavernosa, 2 important framework-building corals on Caribbean reefs, were studied by collecting samples for histology biweekly from November 1982 through November 1983 and weekly from July through September 1984. Additional samples were collected to determine colony size at which reproduction begins and intracolonial variability of reproductive activity. Reproductive effort of $M$. annularis was estimated from elemental analysis of whole polyps and dissected gonads. $M$. annularis is hermaphroditic, with an annual gametogenic cycle that begins in May and ends with spawning in August and/or September. $M$. cavernosa is dioecious, with a prolonged oogenic cycle that begins in November, a briefer spermatogenic cycle that begins in May, and spawning events during July, August and/or September. Spawning for both species appears to occur about $1 \mathrm{wk}$ after the full moon. Both species delay reproduction until colony size reaches about $100 \mathrm{~cm}^{2}$ in surface area. In $M$. annularis, but not in $M$. cavernosa, polyps in the middle of the colony have greater reproductive activity than those near edges of the colony. Ripe gonads of $M$. annularis account for about 30 to $40 \%$ of the biomass of sexually mature polyps. Assuming 10 to $50 \%$ bottom cover by this species, spawning releases 8.4 to $44 \mathrm{~g} \mathrm{C} \mathrm{m}^{-2}$ and 0.9 to $4.7 \mathrm{~g} \mathrm{~N} \mathrm{~m}^{-2}$ to the reef water column on 1 to 2 nights $\mathrm{yr}^{-1}$ The failure of sexual recruits of $M$. annularis to appear on Caribbean coral reefs cannot be attributed to lack of reproductive effort.
\end{abstract}

\section{INTRODUCTION}

Scleractinian corals of the genus Montastrea have been important contributors to reef framework formation in the Caribbean since at least the Miocene (Frost 1977, Budd 1988). The 2 species alive today, Montastrea annularis ${ }^{\circ}$ and $M$. cavernosa, continue this tradition (Goreau 1959, Glynn 1973). The underwater scenery of many Caribbean reefs is dominated by large heads of these species. $M$. annularis occurs over a broad range of depths and reef ecozones: from shallow

\footnotetext{
- Based on electrophoresic, behavioral and morphological data, Knowlton et al. (unpubl, and pers. comm.) suggest that 3 of the distinct morphs of Montastrea annularis are separate species or subspecies. All of the time-series samples included in the present study came from what they call Morph II colonies, which form large mounds with skirts in shallower water. Some of the smaller and deeper colonies collected from The Buoy station (see Materials and methods') may have been of their Morph III. All of the corals used in the El Mario experiment reported in Szmant (1985). and cited here, were of their Morph $I_{i}$ those used in the Enrique experiments reported in the same publication came from Morph II.
}

back-reef environments to deep fore-reef slopes. Colony shape of this species is variable, and an observed change in growth form with depth has been attributed to decrease in light with depth (Dustan 1975, Graus \& Macintyre 1976), as has been the change in corallite morphology (Foster 1979, 1980). Small colonies are abundant as well, but many of these are derived from larger colonies by death of intervening tissues (Hughes \& Jackson 1980), and few appear to be derived from sexual recruits (Hughes 1985, 1988, Hughes \& Jackson 1985). The dominance of the reef by high numbers of large $M$. annularis colonies would lead one to expect large numbers of sexual recruits in this species, but few to none have been found in several recruitment studies (Bak \& Engel 1979, Fitz et al. 1983, Rylaarsdam 1983, Hughes 1988). This has led to the suggestion that $M$. annularis has a low reproductive effort and allocates greater resources towards growth and defense (i.e. a $K$ selected life history strategy) (Bak \& Engel 1979). However, until recently (Szmant 1985, 1986) nothing was known about the sexual reproduction of this species.

Montastrea cavernosa is also abundant on most Caribbean reefs, but colonies are generally smaller in 
size and seldom exceed $1 \mathrm{~m}$ in diameter. Colony morphology is more or less hemispherical or columnar in shape, with colonies on steeper slopes assuming a platey morphology; in general, however, colony shape is more uniform over a similarly extensive depth range (but see Lasker 1981). The slower growth rates of this species are likely less conducive to formation of small colonies by asexual fragmentation, but I know of no studies on this subject for this species. Sexual recruits of M. cavernosa are also rare in recruitment studies (Bak \& Engel 1979, Fitz et al. 1983). Sexual reproduction in this species has not until now been reported upon

In late 1982 I began an intensive 2 yr sampling program to determine the reproductive characteristics of these 2 important reef corals. Preliminary results were briefly summarized in Szmant $(1985,1986)$. The 2 species differ in distribution of gender: Montastrea annularis is hermaphroditic while $M$. cavernosa is gonochoric. Interestingly, the latter species is the only faviid coral known to be gonochoric (Harrison 1985, Richmond \& Hunter 1990). Both have annual cycles of gametogenesis with spawning in the late summer, and neither broods its embryos (Szmant 1986). $M$. annularis exhibits delayed reproduction; colonies $<50 \mathrm{~cm}^{2}$ in surface area are seldom reproductive, while those $>200 \mathrm{~cm}^{2}$ are fully reproductive (Szmant 1985). Furthermore, fragments of large reproductive colonies lost their reproductive ability if they were experimentaly reduced in surface area to less than ca $100 \mathrm{~cm}^{2}$ (Szmant 1985).

The present report presents detailed information on reproductive patterns of these species. In addition to characterizing reproductive periodicity, I investigated variation in reproductive activity within colonies, with respect to colony size and habitat, and estimated reproductive effort for Montastrea annularis

\section{MATERIALS AND METHODS}

Sampling stations. Sampling stations were located in the La Parguera region off the southern coast of Puerto Rico, near the University of Puerto Rico's marine station on Magueyes Island (Fig. 1). The main sampling site was a mid-shelf low-relief patch reef named La India. Water depth was approximately 6 to $8 \mathrm{~m}$. Occasional samples were taken from additional areas: The Buoy, a site at the edge of the insular shelf with water depths exceeding $20 \mathrm{~m}$; El Turrumote, a high-relief mid-shelf bank reef that is part of the most seaward line of reefs; San Cristobal, a mid-shelf bank reef near La India; and El Mario and El Enrique, 2 inshore bank reefs with relatively turbid water.

Sample collection. All samples used to determine the annual reproductive cycles of both species were taken from the La India site. Fifteen large coral heads of each species were numbered and tagged with buoys. The site was mapped and transit lines laid down to aid in localization of the colonies. Sampling was conducted at 2 wk intervals from 19 November 1982 through 8 November 1983 (total of 24 sampling dates). To prevent excessive damage to the colonies, only 5 of the tagged colonies of each species were sampled on each collection date. Thus, each individual colony was only sampled once every 6 wk. For Montastrea cavernosa, which I initially did not know was gonochoric, I had to

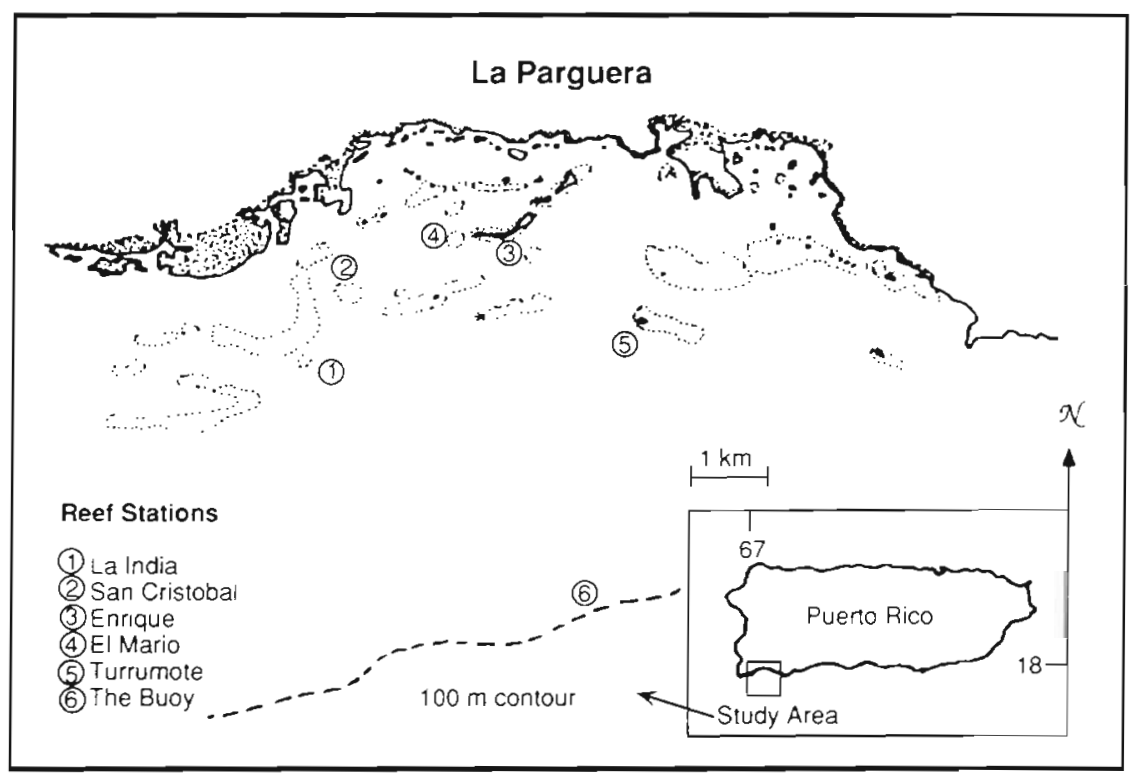

Fig. 1. The La Parguera area of Puerto Rico, showing location of sampling stations 
reorganize the sampling groups half-way through the study in order to sample both males and females during each collection. Sampling frequency was increased to weekly from 3 July to 24 September 1984 (total of 12 sampling dates); 5 to 10 colonies of $M$. annularis and 10 colonies of $M$. cavernosa (some tagged, others not) were sampled each time. At other sites, samples were taken for comparison or for special purposes from arbitrarily chosen, untagged colonies.

Sampling was done by scuba divers using coldchisels or gluts and $2 \mathrm{lb}(1 \mathrm{~kg})$ hammers to remove pieces about $25 \mathrm{~cm}^{2}$ in area from each colony. During the first year, 2 samples were taken from each colony: 1 from the center and 1 from an edge (this practice was discontinued for $M$. cavernosa after 15 March 1983 to avoid excessive damage to smaller colonies. Each sample was placed in a numbered plastic bag, and the bag number and origin of the sample recorded on an under- water slate. Upon return to the dive boat, the samples were removed from the plastic bags, enclosed in small mesh bags with waterproof labels, and submerged in a bucket full of Zenker's fixative (Yevich \& Barszcz 1981).

Two sets of Montastrea annularis samples were collected on 17 August 1983 (2 colonies sampled) and 15 August 1984 (4 colonies sampled) from Turrumote Reef to determine intra-colonial variation in reproductive activity. Single (1983) or duplicate (1984) samples were taken from 4 different areas of each colony: (1) tip of a knob or large 'bump'; (2) flat area in center of colony; (3) free edge or 'skirt' where living polyps were not in contact with any other benthic macro-organism; (4) 'stunted' edge adjacent to any sort of competitor (e.g. sponge, algae, gorgonian). Reproductive activity in each sample was scored as in Szmant (1985) (see Table 1).

A sample of 19 small Montastrea cavernosa colonies
Fig. 2. Montastrea annularis. Gametogenic stages of (A) oocytes and (B) spermaries, observed in histological preparations of samples collected biweekly from November 1982 to November 1983, and weekly from July 1984 through September 1984. Gametocytes were classified as Stages 1 through 4 according to the criteria explained in 'Materials and methods - Histological processing' Plotted values represent percentage of colonies found to contain each stage on each sampling date. $\mathrm{n}$

$=5$ or more for each date

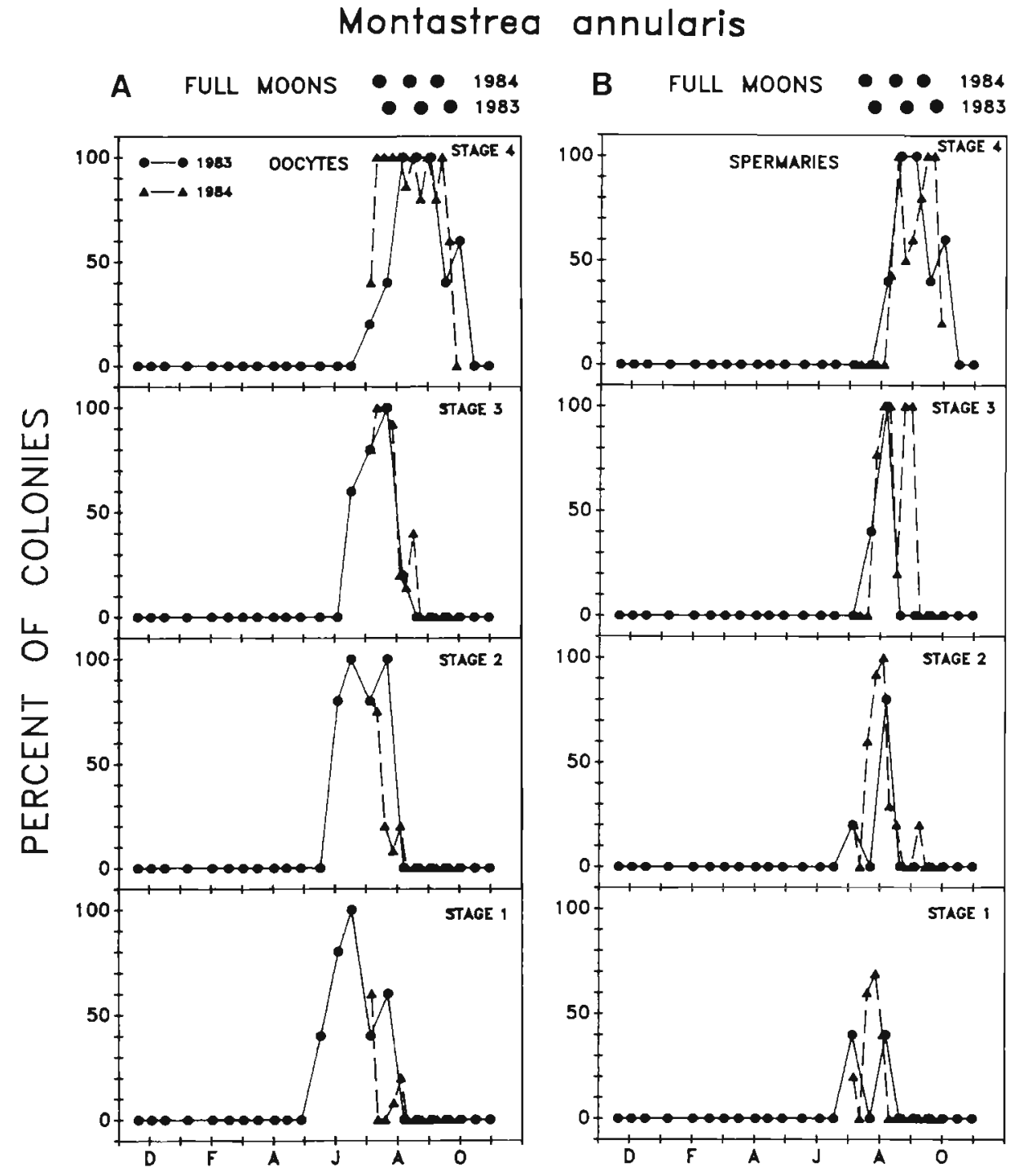


were collected from La India on 20 August 1984, to determine relationship between colony size and onset of sexual reproduction in this species. Each colony was measured before being sampled, and the measurements were used to calculate colony surface area with the appropriate geometrical formula for the shape and relief of each colony. It was not possible to distinguish with assurance between small colonies derived from sexual recruits and those derived by fragmentation from nearby large colonies. Reproductive activity in these samples was also scored as in Szmant (1985), except that since the species is gonochoric, only 3 reproductive categories were possible (see Fig. 6).

Histological processing. Samples were left in the fixative overnight, rinsed in running tap-water for ca $2 \mathrm{~h}$, and then placed into individual containers for decalcification. They were decalcified in a solution of $10 \%$ hydrochloric acid with $0.7 \mathrm{~g} \mathrm{EDTA}^{-1}, 0.008 \mathrm{~g}$ $\mathrm{NaK}$ tartrate $\mathrm{l}^{-1}$ and $0.14 \mathrm{~g} \mathrm{Na}$ tartrate $\mathrm{l}^{-1}$ The acid solution was replaced at least twice per day until no skeletal material could be felt in the samples. The remaining soft tissues were then washed in running tap-water for $24 \mathrm{~h}$, and stored in $70 \%$ ethanol until embedding. Tissues were dehydrated and cleared in a Technicon tissue processor with Technicon solutions S-29 and UC-670, respectively, and embedded in Paraplast. Tissues were trimmed and embedded so that both longitudinal and cross sections of the polyps would be obtained. Histological sections $7 \mu \mathrm{m}$ thick were cut with an AO rotary microtome, stained with Heidenhain's azocarmine-aniline blue (Luna 1968), and examined with light microscopy at magnifications up to $1000 \times$. Ten to 20 polyps, cut at 3 to 4 different levels, were examined for each sample. Gametocytes, when present, were scored as to developmental stage according to the criteria in Szmant et al. (1985) based on gametogenic events described by Giese \& Pearse (1974) and Wourms (1987), with Stage 1 represented by the smallest recognizable gametocytes (primary oocytes and spermatocytes), and Stage 4 by mature ova or sperm ready to be spawned. These data were used to calculate percentage of colonies containing each stage on each sampling date

Quantification of gonad and tissue biomass. Ripe gonads of Montastrea annularis were dissected from freshly collected pieces of coral and from preserved specimens. For fresh samples, pieces of coral were fractured with a hammer and chisel along the longitudinal axis of the polyps. Entire ripe gonads leggs plus spermaries) were dissected from the polyps using finetipped tweezers with the aid of a Wild dissecting microscope, the number of ova counted, and the gonads laid to dry on pre-combusted glass fiber filters. Gonads were also dissected from polyps of preserved, decalcified pieces of tissue left over from the histological samples, and dried on glass fiber filters. In addition, pieces of preserved tissue containing 10 whole polyps were measured (diameter and length of polyps, and surface area of the piece of tissue), dried, and ground to a fine powder with an agate mortar and pestle; the samples used for this test were selected, based on histological observations, to include corals with no gonads, few gonads or many ripe gonads. Both whole gonads on filters and subsamples of the ground polyp tissues were analyzed for carbon and nitrogen content with a Carlo Erba Model 1106 Elemental Analyzer, using acetanilide as the standard. Results (see Table 2) show that there was little difference in gonad biomass estimates made from fresh or preserved material.

\section{RESULTS}

\section{Montastrea annularis}

\section{Reproductive cycle}

Montastrea annularis is hermaphroditic, with both oocytes and spermaries developing in the mid-sections of all 12 mesenteries within each polyp. Details of gametocyte differentiation are similar to those previously described for other scleractinian corals (e.g. Astrangia poculata, Szmant-Froelich et al. 1980; Diploria strigosa, Wyers 1985; Favia fragum, SzmantFroelich et al. 1985) and will not be elaborated upon here. A preliminary plot of the temporal pattern of gametogenesis for the 1982-83 sampling period was published, but not discussed in any detail, in an earlier summary paper (Szmant 1986); the data have been replotted (Fig, 2A, B) and are included here to facilitate comparison with the 1984 data.

Male and female gametes differ in the timing of their developmental periods. No gametocytes of either sex were present in samples taken from November 1982 through April 1983, or in those collected from October through November 1983. Primary oocytes (2 to 4 um in diameter) were first detected in mesenterial endoderm in the 15 May 1983 samples; primary oocytes continued to be present in samples collected through early August in both 1983 and 1984. Further development of oocytes took place after migration into the mesoglea. More advanced stages of oocytes were observed in gonads as the summer progressed. All had advanced to the mature egg stage ( $300 \mu \mathrm{m}$ diameter $)$ by mid-August of both years. Timing of spawning, as evidenced by the disappearance of eggs in the histological preparations, differed for the 2 years, being about $1 \mathrm{wk}$ later in 1983. Ca $50 \%$ of the colonies still had their eggs when sampled on 13 and 27 September 1983, and all colonies had spawned when sampled on 11 October 1983. In 1984, all 
samples still contained eggs on 10 September, only $60 \%$ still had eggs on 17 September, and none of the samples had eggs on 24 September. Partial spawning was observed in some preparations, indicating that individual polyps may spawn more than once. None of the ripe eggs was observed to have zooxanthellae.

Early spermatocytes were not observed until early to mid-July of either year, but mature spermaries (sperm with tails) were already present by mid-August of both years. The pattern of disappearance of spermaries (presumed spawning) was identical to that of the ripe oocytes in 1983, but somewhat different in 1984 in that all samples contained ripe spermaries on 17 September 1984 , and $20 \%$ still had ripe spermaries on 24 September 1984.

Only a few sample dates are available from locations other than the main sampling site at La India. Colonies from the deep site at The Buoy, when sampled on 3 August 1984, appear to have been slightly more advanced than those of La India (no Stage 1 or Stage 2 present). Those from El Mario and El Enrique, on the other hand, still had early stages of gametocytes (Stages 1 and 2) present when sampled on 8 and 15 August 1984, respectively.

\section{Intra-colonial variation in gametogenesis}

The position of a polyp within a large colony was considered to possibly affect whether that polyp was reproductive. Polyps in actively growing parts of a colony (e.g. growing edges) might have fewer resources available for reproduction than did those in slowergrowing parts (e.g. center of colony). Comparison of gamete development in the 1983 biweekly samples taken from the center of each colony with those taken from the edges shows that polyps from both locations had similar stages of gametogenesis in 38 out of the 50 sample pairs $(76 \%)$ in which gametes were found. In the remaining $24 \%$ of the sample pairs, polyps in edge samples either had no gonad development, lagged behind in developmental stage or contained a lower density of gametes than the mid-colony samples.

No descriptive records were made of these midcolony or edge samples at the time of collection. However, it was apparent that there might have been considerable variability in sample characteristics within each of the 2 categories. Some areas within the center of a colony were very knobby, and polyps at the tips of knobs grow faster than those on the flanks of knobs or in flatter areas of a colony. Some edges were actively growing and extended into the water column free from contact with neighboring encrusting organisms, but others were what I called 'stunted', where polyps at the edge of the colony were in contact with competing
Table 1 Montastrea annularis. Comparison of reproductive activity in polyps from different locations within large massive colonies. Single (2 colonies in 1983) or duplicate (4 colonies in 1984) samples were taken from 3 to 4 areas of each colony. Polyps in each sample were examined histologically to determine their reproductive condition. Reproductive activity was scored as in Szmant (1985): (1) no reproductive activity; (2) few oocytes ( 1 to 3 per gonad) present in less than $50 \%$ of polyps; (3) many oocytes ( 6 to 14 per gonad) present in over 80 $\%$ of polyps, but no spermaries; (4) oocytes and spermaries present in all polyps. For description of sample areas, see 'Materials and methods - Sample collection' and 'Results Intra-colonial variation in gametogenesis'

\begin{tabular}{|lcccc|}
\hline $\begin{array}{l}\text { Sample } \\
\text { location (n) }\end{array}$ & \multicolumn{5}{c|}{$\begin{array}{c}\text { Percentage of samples in each } \\
\text { reproductive class } \\
\end{array}$} & (1) & $(2)$ & (3) & $(4)$ \\
\hline Knob, tip (10) & - & - & 20 & 80 \\
Flat, middle (10) & - & 10 & 10 & 80 \\
Free edge (9) & 56 & 11 & - & 33 \\
Stunted edge (8) & 100 & - & - & - \\
\hline
\end{tabular}

encrusting organisms such as sponges, tunicates, forams, etc. To consider the possible effect of these factors, sets of samples were taken from a total of 6 large colonies (Table 1). Polyps taken from mid-colony locations, including both faster-growing tips of knobs and slower-growing flat areas, displayed normal reproductive activity at the time of collection. Most of those collected from colony edges free of contact with other organisms and all of those collected from edges in contact with competing encrusting organisms exhibited no reproductive activity.

\section{Reproductive effort}

Individual gonads contained from as few as 2 to as many as 18 eggs, plus an undetermined number of spermaries; most contained from 11 to 15 eggs (Fig. 3).

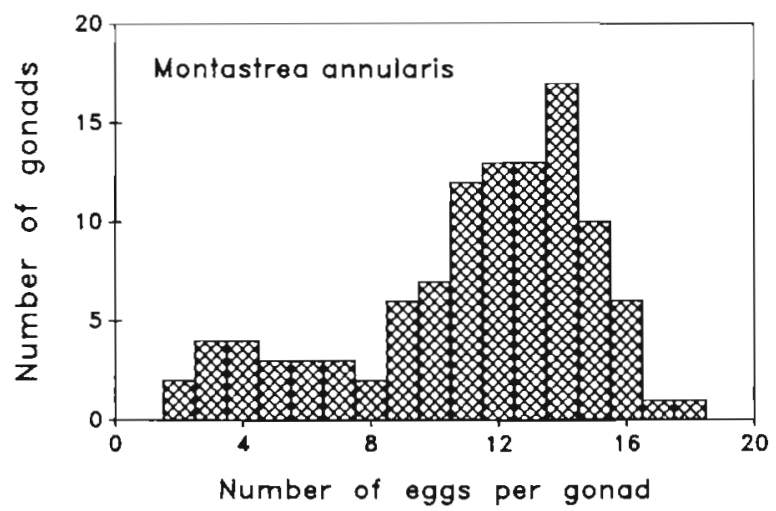

Fig. 3. Montastrea annularis. Frequency histogram of number of eggs per gonad 
Table 2. Montastrea annularis. Estimates of reproductive effort, determined by elemental composition of polyp tissues from colonies with no gonads, few gonads or ripe gonads, and of the gonad index (percentage of polyp $\mathrm{C}$ and $\mathrm{N}$ attributable to gonadal tissues) of the latter. Each polyp was assumed to have 12 gonads. Values are means $\pm \mathrm{SD}_{i} \mathrm{n}=5$ for each of the polyp tissue types; $n=10$ for fresh gonads and $n=13$ for preserved gonads

\begin{tabular}{|c|c|c|c|c|c|c|}
\hline \multirow{2}{*}{$\begin{array}{l}\text { Reproductive } \\
\text { status }\end{array}$} & \multirow{2}{*}{$\begin{array}{c}\text { Dry wt } \\
\left(\mathrm{mg} \mathrm{polyp}^{-1}\right)\end{array}$} & \multicolumn{2}{|c|}{ Mean polyp: } & \multicolumn{2}{|c|}{ Polyp biomass } & \multirow{2}{*}{$\begin{array}{l}\mathrm{C} / \mathrm{N} \text { atomic } \\
\text { ratio }\end{array}$} \\
\hline & & $\begin{array}{l}\text { Length } \\
(\mathrm{mm})\end{array}$ & $\begin{array}{l}\text { Diam. } \\
\text { (mm) }\end{array}$ & $\begin{array}{c}\mathrm{C} \\
\text { (ug-at. polyp }\end{array}$ & $\left.\begin{array}{c}\mathrm{N} \\
(\mu \mathrm{g}-\text { at. } \\
\text { polyp } \\
-1\end{array}\right)$ & \\
\hline No gonads & $2.34 \pm 0.39$ & $3.16 \pm 0.42$ & $2.49 \pm 0.28$ & $101 \pm 21$ & $10.7 \pm 1.1$ & $9.6 \pm 2.2$ \\
\hline Few gonads & $2.60 \pm 0.40$ & $3.61 \pm 0.45$ & $2.45 \pm 0.25$ & $118 \pm 19$ & $12.8 \pm 3.6$ & $9.6 \pm 2.1$ \\
\hline Ripe gonads & $3.05 \pm 0.37$ & $3.69 \pm 0.62$ & $2.43 \pm 0.31$ & $140 \pm 22$ & $15.2 \pm 3.3$ & $9.5 \pm 1.6$ \\
\hline Gonad source & & $\begin{array}{c}\text { Dry wt } \\
\left.\mu g g^{-1} \operatorname{gad}^{-1}\right)\end{array}$ & $\begin{array}{c}\mathrm{C} \\
(\mu \mathrm{g}-\text { at. gonad } \\
\end{array}$ & (ug-at. & $\left.\operatorname{nad}^{-1}\right)$ & atomic ratio \\
\hline Fresh & & - & $4.00 \pm 1.77$ & 0.40 & 0.11 & $.9 \pm 1.3$ \\
\hline Preserved & & $94 \pm 32$ & $4.81 \pm 1.90$ & 0.39 & 0.21 & $.4 \pm 1.3$ \\
\hline \multicolumn{7}{|c|}{ Gonad tissue as percentage of polyp tissue: } \\
\hline Fresh & & & 34 & & 32 & \\
\hline Preserved & & & 41 & & 31 & \\
\hline
\end{tabular}

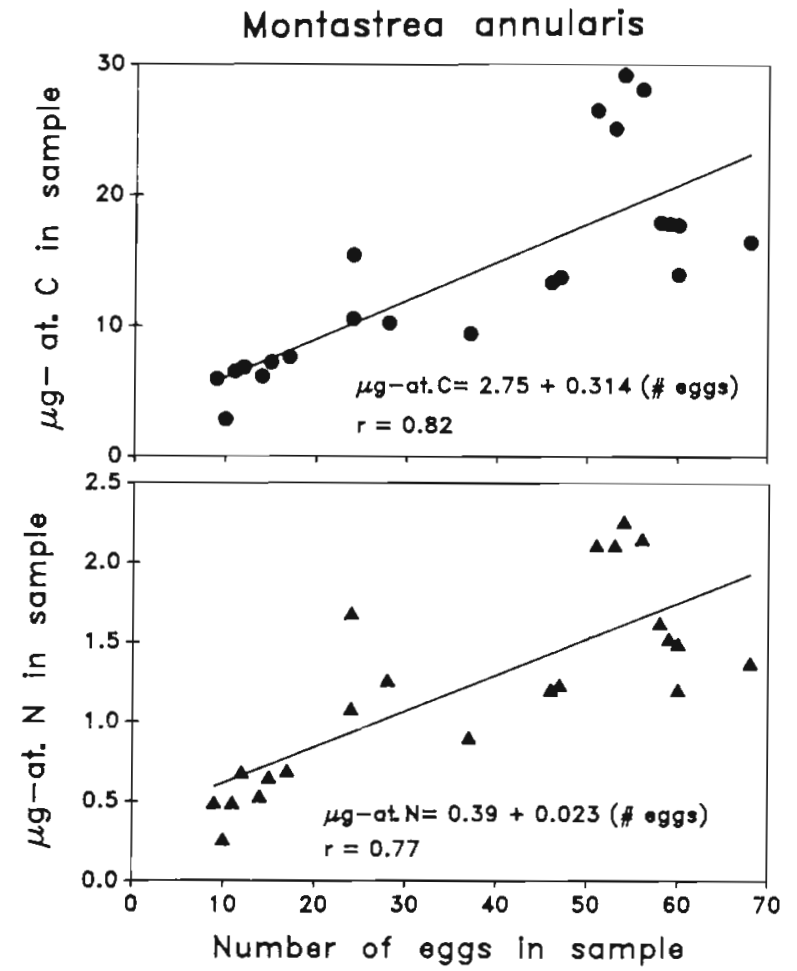

Fig. 4. Montastrea annularis. Carbon and nitrogen content of groups of dissected whole ripe gonads plotted against total number of eggs in the sample. Elemental analysis was performed on a Carlo Erba Model 1106 Elemental Analyzer, on samples containing from 2 to 5 whole gonads. Regressions for both $\mathrm{C}$ and $\mathrm{N}$ are statistically significant $(\mathrm{p}<0.01)$. \# eggs: No. of eggs
The number of eggs per gonad was more or less consistent (range $= \pm 2$ ) within each colony, but differed among colonies.

Polyps of reproductive and non-reproductive colonies of Montastrea annularis were not significantly different from each other in length or diameter ( $t$-test, 8 d.f., $p \gg 0.05$ ), but reproductive polyps had significantly higher dry weights and $\mathrm{C}$ and $\mathrm{N}$ biomasses than did non-reproductive polyps ( $t$-test, 8 d.f., $p \ll 0.02$ ) (Table 2). Polyps that had a few gonads were intermediate in biomass. Polyps with ripe gonads had about $140 \mu \mathrm{g}$-at. $\mathrm{C}$ and $15 \mu \mathrm{g}$-at. $\mathrm{N}$ in their tissues, of which about 50 $\mu \mathrm{g}$-at. $\mathrm{C}(38 \%)$ and $4.8 \mu \mathrm{g}$-at. $\mathrm{N}(32 \%)$ were in gonad tissues (Table 2). Gonad $\mathrm{C}$ and $\mathrm{N}$ biomass increased linearly with number of eggs (Fig. 4), suggesting that the biomass of individual eggs was more or less constant. The biomass of individual eggs could not be estimated from these data because the samples contained an unknown amount of spermary tissue.

\section{Montastrea cavernosa}

\section{Reproductive cycle}

Montastrea cavernosa is gonochoric. Only 2 hermaphroditic samples were found in over 300 samples of 140 colonies; these were ripe (Stage 4) male colonies collected on 10 September 1984 that had primary oocytes in their gonads. None of the 15 tagged colonies 
Fig. 5. Montastrea cavernosa Gametogenic stages in (A) female colonies and (B) male colonies, observed in histological preparations of samples collected biweekly from November 1982 to November 1983, and weekly from July 1984 through September 1984. Gametocytes were classified as Stages 1 through 4 according to the criteria explained in Materials and methods - Histological processing' Plotted values represent percentage of colonies found to contain each stage on each sampling date. n $=5$ or more for each date

\section{Montastrea cavernosa}

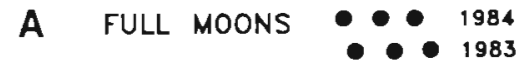

B FULL MOONS $\bullet \bullet 1984$

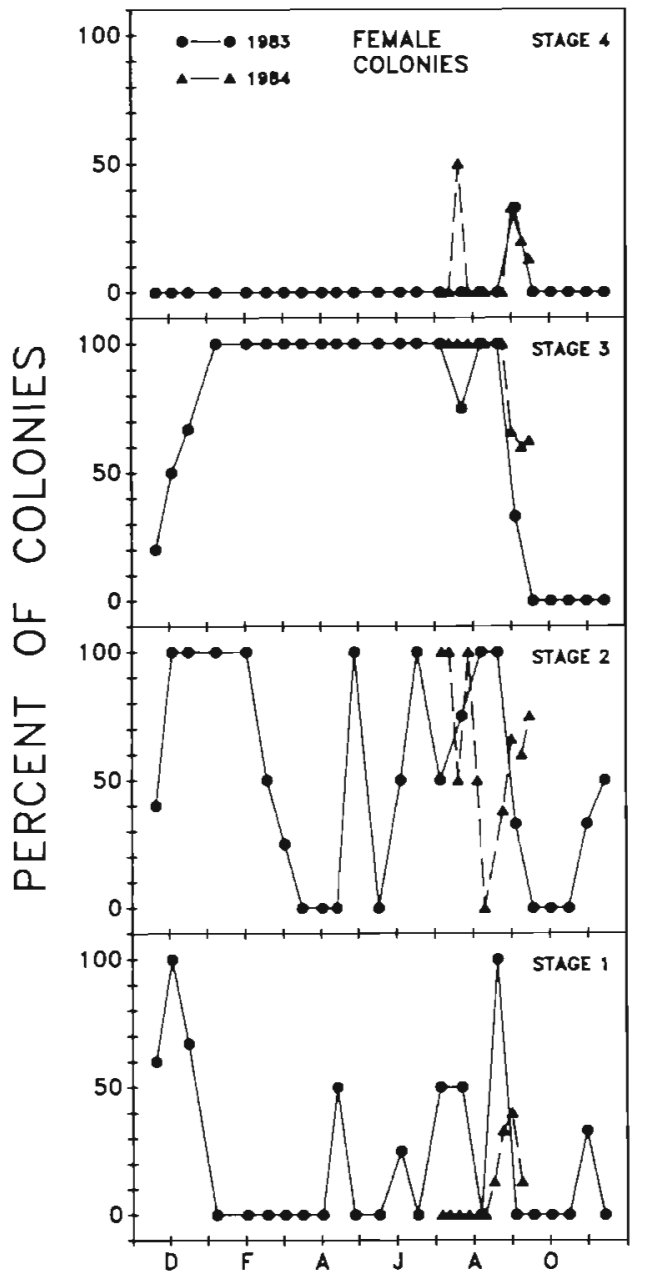

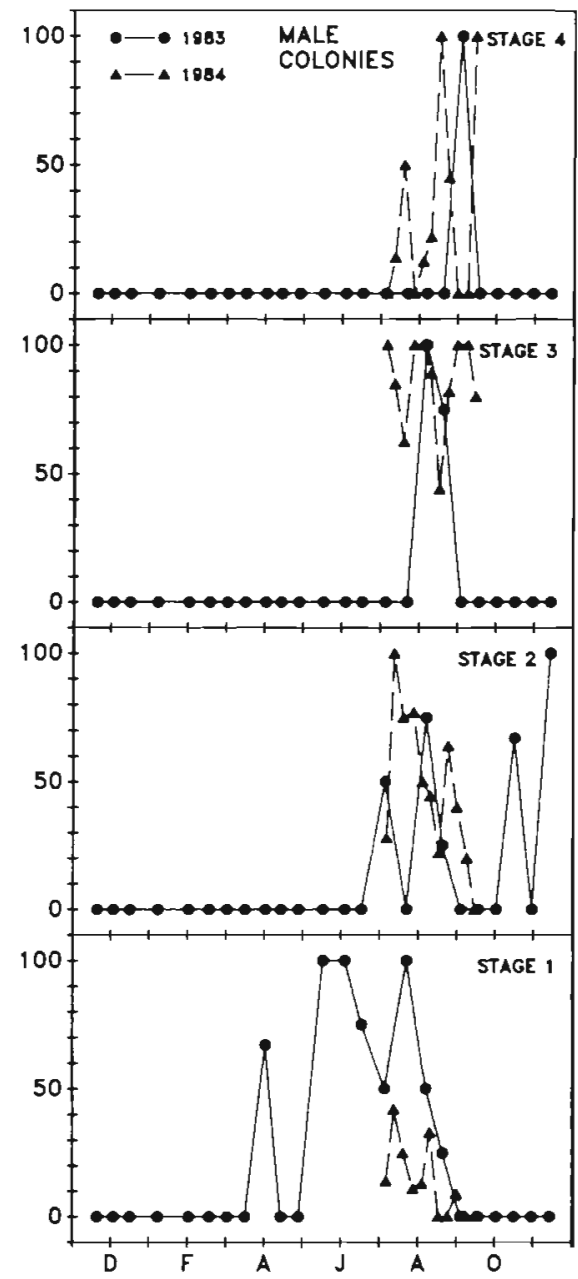

changed sex during the 2 yr sampling program. The sex ratio of our initial sample from La India was ca 1:1 (with $\mathrm{n}=15$ ). Later samples, however, yielded male:female ratios ranging from 0.62 to 4.5 (mean of $1.8 \pm 0.44, \mathrm{n}=12$ sets of samples), with a composite male:female ratio of 2.4 for the 140 colonies sampled.

Male and female colonies have different reproductive cycles (Fig. 5). Oogenesis occurs throughout much of the year except for 1 to 2 mo following spawning (Fig. 5A). Primary oocytes (3 to $6 \mu$ m diameter, Stage 1) were observed in histological preparations of samples collected during winter 1982-83, and sporadically in those collected during both summers. Oocytes classified as Stage 2 were seen in most samples collected from December through September. Stage 3 oocytes (vitellogen accumulation phase) were present in all samples collected from January through late August. Stage 4 oocytes (ready to spawn) are only present for a few days before spawning and thus are less likely to be observed with infrequent sampling; they were only seen in a few samples collected in late August 1983, and in mid-July and late August 1984 (Fig. 5A). Ripe eggs did not contain zooxanthellae. Spermatogenesis, as in Montastrea annularis, requires less time for completion. Primary spermatocytes began to appear in samples collected in April and May 1983, and were still present in samples collected through August. Stage 2 spermatocytes were not found until mid-July 1983 but were present in all July and August 1984 samples. The timing of occurrence of Stage 3 spermaries also differed between the 2 years: in 1983 they were only found during August, but they were present throughout July and August of 1984. Stage 4 spermaries (sperm with tails) were only seen in 1 late August sample during the 1983 season, but 3 peaks in abundance occurred during summer 1984 (Fig. 5B). By 30 August 1983, $67 \%$ of 
females sampled had no Stage 3 or 4 oocytes, and no mature gametes of either sex were found in samples collected on 13 September 1983, suggesting that spawning had occurred sometime between 16 August and 13 September 1983. In contrast, all samples collected on 10 September 1984, the last sampling date, still had Stage 3 and 4 spermatocytes.

Twenty-one colonies from The Buoy sampled on 3 August 1984 at depths greater than $20 \mathrm{~m}$ were in the same reproductive state as shallow-water colonies at that time.

Intra-colonial variation in gametogenesis

Only 25 samples were available for comparing reproductive activity in the middle of colonies vs along their edges. For all except 1 of these pairs of samples, the middle and edges were in the same reproductive state. For the remaining pair, the middle sample was reproductive while the edge sample was not.

Effect of colony size on reproduction

The 19 small colonies of Montastrea cavernosa collected on 19 August 1984 were divided into 5 size classes based on estimated colony surface area. Frequency of occurrence of 3 different reproductive states (non-reproductive, a few gametes, fully reproductive) among the various size classes of $M$. cavernosa is plotted in Fig. 6. Both males and females were found among the small colonies, indicating that gender is not related to colony size. Only 1 colony out of the 19, a female $170 \mathrm{~cm}^{2}$ in size which had numerous ova in her gonads, could be considered reproductively mature.

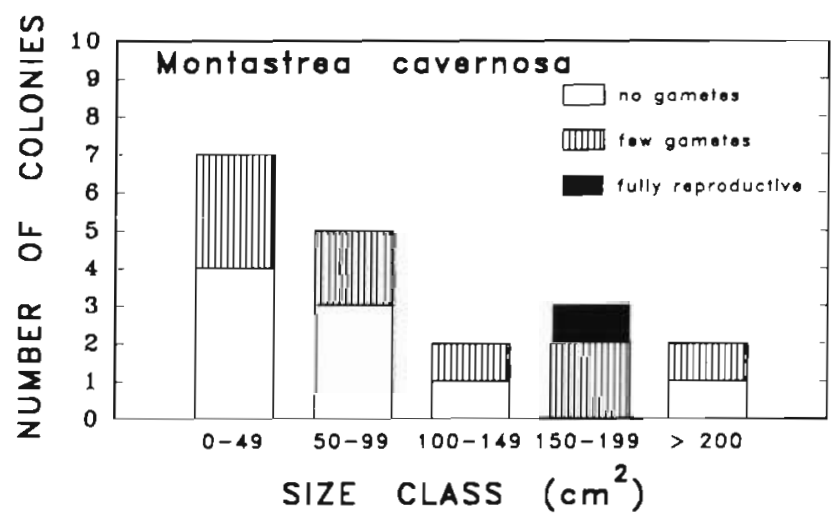

Fig. 6. Montastrea cavernosa. Stacked histogram of reproductive state of small coral colonies. Surtace area of each colony, estimated from measurements of colony dimensions before sampling, was used to divide the colonies into size classes. The reproductive status of each colony was determined by histological examination of its tissues
One-half of the remainder had only a few oocytes or spermatocytes in their mesenteries; the other half displayed no evidence of gametogenesis. The largest of the small colonies sampled was $264 \mathrm{~cm}^{2}$ in living area and contained no gametes.

\section{DISCUSSION}

The 2 congeners of Montastrea studied here have annual cycles of gametogenesis that terminate with brief periods of broadcast spawning, and planktonic development of their embryos to the planula stage. Zooxanthellae were not present in eggs of either species, indicating that algal symbionts must be acquired de novo during the planktonic phase or after settlement. This is the pattern that appears to be most typical for reef corals, especially for the structurally dominant coral species of both Atlantic and IndoPacific reefs (Harrison et al. 1984, Babcock et al. 1986, Szmant 1986, Richmond \& Hunter 1990). Given the preponderance of broadcast spawning as a mode of gamete release among scleractinian corals, I propose that brooding with multiple planulation cycles per year (which for decades was thought to be the norm for reef corals) be considered a secondarily derived reproductive pattern characteristic of many of the more opportunistic, short-lived coral species (Rinkevich \& Loya 1979, Szmant 1986, Richmond \& Hunter 1990).

Reproductive characteristics of the 2 Montastrea species differ in 2 important respects: distribution of gender and duration of the oogenic cycle. The gonochorism of M. cavernosa, generally but not always the less abundant of the 2 species, would seem to be a disadvantageous trait for a sessile animal with external fertilization: rates of fertilization might be low if colonies of opposite sex were not close together. Synchronous spawning and production of sperm attractants (Miller 1985) are traits that would be especially helpful to sessile corals such as $M$. cavernosa for overcoming the disadvantages of gonochorism. The overall male:female ratio of 2.4 estimated based on all samples taken in this study should be considered tentative, but indicates that on some reefs poor fertilization success and gamete wastage would occur. Soong (1990) also observed a large variability in sex ratio for this species on Panamanian reefs, but he reported an overall sex ratio of $1: 1$.

The oogenic cycle of Montastrea annularis is much shorter than that of $M$. cavernosa. Oogenesis in $M$. annularis begins in the early summer and is completed in less than 4 mo. In $M$. cavernosa, however, oogenesis occurs throughout most of the year, with a new oogenic cycle beginning 1 to 2 mo after spawning. Spermatogenesis in both species occurs over a briefer 
period, but again, the spermatogenic period of $M$. annularis is shorter than that of $M$. cavernosa. Thus, colonies of $M$. annularis and male colonies of $M$. cavernosa have brief periods of intense gametogenic activity, during which the rate of biomass allocation to reproduction must be much more rapid than for female colonies of $M$. cavernosa. Diversion of resources to reproduction has been suggested to cause the production of annual high-density bands in skeletons of massive corals (Buddemeier \& Kinzie 1976, Wellington \& Glynn 1983). If so, it could be expected that reproductive colonies of $M$. annularis and male colonies of $M$. cavernosa would have distinct annual density bands in their skeletons, while non-reproductive (e.g. young or small) colonies of $M$. annularis and female colonies of $M$. cavernosa would not have distinct density bands. Large colonies of $M$. annularis do have distinct highdensity bands that form during the summer months (Hudson 1981, Leder et al. in press), but there appears to be no difference between density patterns of the 2 sexes in $M$. cavernosa (author's unpubl. preliminary data). The high-density bands in $M$. annularis could be attributed to the high energy demands of an intense gametogenic effort imposing a sudden energy limitation on other physiological processes; the higher annual growth rates that result from deposition of lowdensity skeleton throughout much of the year may result from the absence of energy allocation to reproduction during those months. Examination of the density structure in young pre-reproductive colonies of $M$. annularis would help clarify this possibility. On the other hand, the absence of differences in skeletal banding patterns between male and female colonies of $M$. cavernosa suggests that energy allocation to sexual reproduction may not be involved in production of density bands.

Synchronous spawning within populations and between species is a topic that has received much attention since the phenomenon of 'mass spawning' was observed for corals on the Great Barrier Reef (Harrison et al. 1984, Willis et al. 1985, and others). Spawning was not observed in the field for either species of Montastrea, even though we made dives every other night throughout the entire summer of 1984. The spawning periods presented here were derived solely from the histologic samples; spawning was judged to have occurred during the interval between sample dates when samples with ripe gametes were followed by samples with no or immature gametes. The developmental pattern of the spermaries may be a better indicator of spawning times, because ripe spermaries are easier to recognize than ripe eggs.

Spermatogenesis began and spawning occurred about 1 wk earlier in 1984 than in 1983 for both species of Montastrea. This agrees with a lunar control of spawning, since the full moons of 1984 occurred 1 wk earlier than those of 1983. In 1983 (biweekly sampling) both species spawned about 1 wk after the full moon (third lunar quarter) of August. For Montastrea annularis only, a second smaller episode of spawning may have occurred about the time of the third quarter moon of September 1983 (Fig. 2B). During the 1984 season, the weekly sampling schedule allowed more cycles of spawning to be distinguished: for $M$. annularis, 2 episodes during the third lunar quarters of August and September, and for $M$. Cavernosa, 3 episodes during the third lunar quarters of July, August and September. The histological evidence suggests that individual colonies had multiple spawning episodes, as opposed to different colonies spawning completely during each episode. The only reported field observations of spawning by these species agree with the timing derived from the histological analysis: spawning by both species was observed in Bermuda about 2 to $3 \mathrm{~h}$ after sunset on 6 to $9 \mathrm{~d}$ after the full moons of August and September 1985 and July and August 1986 (Wyers et al. 1991). Spawning of M. cavernosa was observed in the Texas Flower Gardens $8 \mathrm{~d}$ after the full moon of August 1990 (G. Rinn pers. comm.). Spawning of clouds of sperm by 1 colony during the late afternoon was followed by spawning by numerous individuals of both sexes later that night (Rinn \& Bright unpubl.). Spawning times for these 2 species on Panamanian reefs, inferred from histological techniques, also occurred in late summer (August/September 1987 and 1988; Soong 1990). Thus, throughout their geographic range, these species appear to spawn about 1 wk after the full moon during the late part of the summer.

The lunar timing of spawning of these 2 species is similar to the timing of spawning observed for many reef corals on the Great Barrier Reef (Willis et al. 1985). Interestingly, from Bermuda through Panama, spawning season appears to be uniform, even though annual temperature and light cycles differ greatly over this latitudinal range. This contrasts with information available for Indo-Pacific corals, for which latitudinal variation in spawning season and spawning synchrony (less synchrony in areas with smaller annual temperature range) have been observed (Richmond \& Hunter 1990). More work is needed to determine whether the larger annual seawater temperature range at Bermuda (12 to $13^{\circ} \mathrm{C}$; Wyers 1985 ) results in greater spawning synchrony than does the 3 to $4^{\circ} \mathrm{C}$ annual temperature range in locations such as Puerto Rico or Panama. The association of spawning with lunar period may represent the fundamental timing mechanism used by corals (and many other marine invertebrates) to achieve synchronized spawning within a population, while fac- 
tors such as temperature and photoperiod, which have important roles in regulating reproductive cycles (Giese \& Pearse 1974), may control initiation of gametogenesis. The timing of each season's spawning events will thus depend on where the lunar cycle falls with regard to the annual gametogenic cycle. In Australia, spawning follows the full moons of late spring (October and November) when temperatures are rising and photoperiod increasing, while in Puerto Rico spawning occurs during the warmest months of the year when photoperiod is decreasing.

The age and size (for solitary animals, the 2 are usually correlated) at which sexual reproduction begins, and the reproductive output per individual ${ }_{r}$ are important components of an animal's life-history strategy. For colonial animals such as corals, where age and size are not necessarily correlated because of partial mortality and fragmentation (Hughes \& Jackson 1980, Highsmith 1982), size is as important as age in determining sexual maturity (Connell 1973, Kojis \& Quinn 1985, Szmant 1985). Some species of coral such as Favia fragum (Szmant-Froelich et al. 1985) and Goniastrea favulus (Kojis \& Quinn 1985) begin producing gametes when the colonies have only a few polyps. and reduction in size might be expected to have only a short-term or no inhibitory effect on reproduction. Both species of Montastrea, however, delay reproduction for an estimated 7 to $10 \mathrm{yr}$, and/or have only a minimal reproductive effort until they reach ca $100 \mathrm{~cm}^{2}$ or more in colony size (Szmant 1985, and present results), i.e. about 700 polyps for $M$. annularis and 400 polyps for M. cavernosa.

The dogma is that reproductive delay allows an organism to grow more quickly to a size that is safe against predation and other causes of death, based on the premise that animals cannot sustain maximal growth and reproduction at the same time (see reviews by Sebens $1987 \mathrm{a}, \mathrm{b})$. The physiological basis of the reproductive delay in solitary or polymorphic colonial organisms is not well understood, but can be conceived to be based on a repression of gametogenesis until the animal progresses through a series of developmental stages, after which differentiation of reproductive cells or sub-units occurs. However, a mechanism by which reproductive delay could be effected in non-polymorphic colonial animals has not been proposed. For most corals, the time it takes for a new budded polyp to reach its final 'adult' length and diameter will be limited by the linear rate at which the colony's skeleton grows in height. For a coral such as Montastrea annularis which has a linear skeletal growth rate of about 0.5 to $1 \mathrm{~cm} \mathrm{yr}^{-1}$ (Hudson 1981, Leder et al. in press, author's unpubl, data) individual polyps should reach their maximal size in less than a year. Thus, reproductive delay at the colony level implies either that polyps within a colony have some means of sensing how big the colony is (and some means of triggering reproduction when that size is reached), or that some other process related to colony growth or size has an effect on the ability of individual polyps to become reproductive.

The hypothesis that I posed and attempted to test in this study was that polyps very near, and actively contributing to, the production of new polyp buds would not be active in reproduction. The colony growth process of a typical mounding coral such as Montastrea annularis is as follows. During the first few years of founding of a new colony from a planula, the young colony grows mostly by encrusting lateral growth of coenosteal tissue (= rapid increase in surface area; Vaughn 1916, author's pers. obs.), with new polyps arising by extra-tentacular budding from this new coenosteum. The new polyps will be small, short and far apart. As the small colony increases in diameter, the older central polyps become distanced from the colony perimeter, where most of the active growth (new surface area) and budding takes place. Furthermore, successive budding events in the central area of the spreading colony will result in the inter-calicular distances decreasing to a limit where no more buds can be inserted (i.e. budding becomes surface-area limited). Space for insertion of new buds in the colony center only becomes available as the colony grows upwards, and colony shape changes from flattened to hemispherical. During the first few years of colony growth, a given increase in height (increase in colony radius) will give rise to proportionally more new surface area than later on, when colony height is larger. Thus, initially, even the oldest central polyps will be involved in frequent budding. After a few years, however, the rate of new bud insertion will decrease, leaving central polyps 'free' to enter into sexual reproduction.

Based on this proposed mechanism for reproductive delay, I hypothesized that polyps in colony parts with high growth rate (e.g. tips of knobs, free edges) would exhibit less reproductive activity than those in slowergrowth (e.g. flat) areas, since a larger proportion of polyps in the growth areas would be involved in budding. I also hypothesized that polyps that are in perimeter areas where growth is stunted by contact with competitors (and that should have low rates of budding) would not be reproductive because of the energy demands of competition, defense and repair. The results in Table 1 show that for Montastrea annularis the first hypothesis was only partially supported: most polyps in fast-growing areas at the edges of colonies were non-reproductive, but those in fast-growing areas in the center of colonies were fully reproductive. The second hypothesis was supported by these data: none of the polyps collected from stunted edges contained 
any gametes. This experiment should be repeated with greater attention given to measuring actual rates of new surface-area generation and budding, as well as to energy demands placed upon perimeter polyps by neighboring organisms. The experiment also needs to be conducted for $M$. cavernosa, since preliminary data indicating that edge polyps are fully reproductive differ from similar data collected by Soong (1990) in Panama that show edge polyps to be non-reproductive, and adjacent polyps (1 row in from the edge) to have lowered gamete production.

Reproductive effort was only measured for Montastrea annularis. In this species, about 30 to $40 \%$ of the biomass of ripe polyps is made up of gonads. In contrast to $M$. cavernosa, where gametogenesis is gradual, accumulation of reproductive biomass in $M$. annularis takes place in less than $4 \mathrm{mo}$. This means that polyps of $M$. annularis must accumulate new biomass or re-allocate old biomass for gametogenesis at the rate of $10 \% \mathrm{mo}^{-1}$. The results in Table 2 suggest that new biomass is accumulated during the reproductive period. Porter (1985) has estimated that in Jamaica, only the shallowest-dwelling colonies of $M$. annularis have an excess of zooxanthellae-derived photosynthetic materials over that needed for coral and zooxanthellae respiration, and that colonies living between 10 and $50 \mathrm{~m}$ depth must acquire exogenous sources of food to supply between 10 to $30 \%$ of their respiratory needs. Reported respiration rates of $M$. annularis range from 300 to $1000 \mathrm{nmol} \mathrm{O}_{2} \mathrm{~cm}^{-2} \mathrm{~h}^{-1}$ (Davies 1980, SzmantFroelich et al. 1981, Porter 1985, Szmant et al. 1990, unpubl.). The accumulated biomass of gonads represents an accumulation of $128 \mathrm{nmol} \mathrm{C} \mathrm{cm}{ }^{-2} \mathrm{~h}^{-1}$ if distributed evenly over the 4 mo reproductive season. "This represents a carbon demand equivalent to an additional 15 to $45 \%$ of respiratory demand (assuming a $\mathrm{RQ}$ of 1.0 ) that the coral must meet on a daily basis from exogenous sources. Thus, polyps of this species must be capable of supplementing their zooxanthellaederived nourishment by capturing/acquiring large amounts of exogenous carbon and nitrogen biomass on a fairly regular basis.

In any case, it is evident that Montastrea annularis diverts a significant proportion of its annual production to sexual reproduction. On reefs where $M$. annularis can make up 10 to $50 \%$ of the bottom cover, this species will spawn the equivalent of 8.4 to $44 \mathrm{~g} \mathrm{C} \mathrm{m}^{-2}$ and 0.9 to $4.7 \mathrm{~g} \mathrm{~N} \mathrm{~m}^{-2}$ into the water column on 1 or 2 nights per year. ' Depending on whether this produc-

\footnotetext{
- Estimated as 7 polyps $\mathrm{cm}^{-2} \times 4.4 \mu \mathrm{g}$-at. $\mathrm{C} \mathrm{gonad}^{-1} \times 12$ gonads polyp ${ }^{-1} / 2880 \mathrm{~h} \times 1000 \mathrm{ng}$-at. $\mu \mathrm{g}$-at. ${ }^{-1}$

- Estimated as 10 to $50 \%$ planar cover $\times 2$ (relief correction) $\times 70000$ polyps $\mathrm{m}^{-2} \times 53 \mu \mathrm{g}$-at. gonad $\mathrm{C}$ polyp ${ }^{-1}$ (or 4.8 $\mu g$-at. gonad $\mathrm{N}$ polyp ${ }^{-1} \times 12$ (atomic weight of $\mathrm{C}$ )
}

tion is consumed by reef planktivores or is carried away from the reef, spawning by $M$. annularis will constitute a large transfer of energy to the reef food-chain, or a large resource loss from the reef ecosystem. In view of this large reproductive effort, the failure of $M$. annularis progeny to appear among newly settled corals on Caribbean reefs must be attributed to factors such as poor viability of embryos, high mortality in the plankton or poor recruitment success.

Acknowledgements. This project would not have succeeded but for the dedication of Linda Riggs in carrying out the sampling schedule come rain or shine. The Department of Marine Sciences, University of Puerto Rico, is thanked for generous space and logistic support. Thanks go to R. Armstrong, M. Basile, M. Reutter and S. Steiner for assistance with field collection and histological processing of the samples. Lisa Erman executed the $\mathrm{C}$ and $\mathrm{N}$ biomass work, and Nancy Gassman helped with data analysis and preparing graphs. Field work was supported by NSF grants OCE-8208560 and OCE-8315191, and by a small research grant from the University of Puerto Rico; manuscript preparation was supported by NSF grants OCE-8515399 and OCE-89-00095.

\section{LITERATURE CITED}

Babcock, R. C., Bull, G. D., Harrison, P. L., Heyward, A. J., Oliver, J. K., Wallace, C. C., Willis, B. L. (1986). Synchronous spawnings of 105 scleractinian coral species on the Great Barrier Reef. Mar Biol. 90: 379-394

Bak, R. P. M., Engel, M. S. (1979). Distribution, abundance and survival of juvenile hermatypic corals (Scleractinia) and the importance of life history strategies in the parent coral community. Mar. Biol. 54: 341-352

Budd, A. F. (1988). Large-scale evolutionary patterns in the reef-coral Montastrea: the role of phenotypic plasticity. In: Choat, J. H. et al. (eds.) Proceedings of the Sixth International Coral Reef Symposium, Australia, Vol. 3. Sixth International Coral Reef Symposium Executive Committee, Townsville, p. 393-398

Buddemeier, R. W. Kinzie, R. A., (1976). Coral growth. Oceanogr mar. Biol. A. Rev. 14: 183-225

Connell, J. H. (1973). Population biology of reef-building corals. In: Jones, O. A., Endean, R. (eds.) Biology and geology of coral reefs, Vol. 2. Academic Press, New York, p. $205-245$

Davies, P. S. (1980). Respiration in some Atlantic reef corals in relation to vertical distribution and growth form. Biol. Bull. mar. biol. Lab., Woods Hole 158: 187-193

Dustan, P. (1975). Growth and form in the reef-building coral Montastrea annularis. Mar. Biol. 33: 101-107

Fitz, C., Reaka, M. L., Bermingham, E., Wolf, N. G. (1983). Coral recruitment at moderate depths: the influence of grazing. NOAA Symp. Ser. Undersea Res. 1 89-96

Foster, A. B. (1979). Phenotypic plasticity in the reef corals Montastrea annularis (Ellis und Solander) and Siderastrea siderea (Ellis and Solander). J. exp. mar. Biol. Ecol. 39: $25-54$

Foster, A. B. (1980). Environmental variation in skeletal morphology within the Caribbean reef corals Montastrea annularis and Siderastrea siderea. Bull mar Sci. 30: $678-709$

Frost, S. H. (1977). Miocene to Holocene evolution of Carib- 
bean province reef-building corals. In: Taylor, D. L. (ed.) Proceedings of the Third International Coral Reef Symposium, Miami, Vol. 2. Rosenstiel School of Marine and Atmospheric Science, University of Miami, p. 353-359

Giese, A. C., Pearse, J. S. (1974). Introduction: General principals. In: Giese, A. C., Pearse, J. S. (eds.) Reproduction of marine invertebrates, Vol. 1 Academic Press, New York, p. $1-49$

Glynn, P. W. (1973). Aspects of the ecology of coral reefs in the Western Atlantic region. In: Jones, O. A., Endean, R. (eds.) Biology and geology of coral reefs, Vol. 2. Academic Press, New York, p. 271-324

Goreau, T. F. (1959). The ecology of Jamaican coral reefs. Ecology 40: 67-90

Graus, R. R., Macintyre, I. G. (1976). Variation in growth forms of the reef coral Montastrea annularis (Ellis and Solander): a quantitative evaluation of growth response to light distribution using computer simulation. In: Rützler, K., Macintyre, I. G. (eds.) The Atlantic barrier reef ecosystem at Carrie Bow Cay, Belize, I. Smithson. Contr. mar. Sci. 12: $441-464$

Harrison, P. L. (1985). Sexual characteristics of scleractinian corals: systematic and evolutionary characteristics. In: Gabrie, C. et al. (eds.) Proceedings of the Fifth International Coral Reef Congress Tahiti, Vol. 4. Antenne Museum - EPHE, Moorea, French Polynesia, p. 337-342

Harrison, P. L., Babcock, R. C., Bull, G. D., Oliver, J. K., Wallace, C. C., Willis, B. L. (1984). Mass spawning in tropical reef corals. Science 223: 1186-1188

Highsmith, R. C. (1982). Reproduction by fragmentation in coraIs. Mar. Ecol. Prog. Ser. 7: 207-226

Hudson, H. J. (1981). Growth rates in Montastrea annularis: a record of environmental change in Key Largo National Marine Sanctuary, Florida. Bull. mar. Sci. 31 444-459

Hughes, T. P. (1985). Life histories and population dynamics of early successional corals. In: Gabrie, $\mathrm{C}$. et al. (eds.) Proceedings of the Fifth International Coral Reef Congress, Tahiti, Vol. 4. Antenne Museum - EPHE, Moorea, French Polynesia, p. 101-106

Hughes, T.P. (1988). Long-term dynamics of coral populations contrasting reproductive modes. In: Choat, J. H. et al. (eds.) Proceedings of the Sixth International Coral Reef Symposium, Australia, Vol. 2. Sixth International Coral Reef Symposium Executive Committee, Townsville, p. 721-725

Hughes, T. P., Jackson, J. B. C. (1980). Do corals lie about their age? Some demographic consequences of partial mortality, fission, and fusion. Science 209: 713-715

Hughes, T. P., Jackson, J. B. C. (1985). Population dynamics and life histories of foliaceous corals. Ecol. Monogr. 55: $141-166$

Kojis, B. L., Quinn, N. J. (1985). Puberty in Goniastrea favulus. age or size limited? In: Gabrie, C. et al. (eds.) Proceedings of the Fifth International Coral Reef Congress, Tahiti, Vol 4. Antenne Museum - EPHE, Moorea, French Polynesia, p 289-293

Lasker, H. R. (1981). Phenotypic variation in the coral Montastrea cavernosa and its effects on colony energetics. Biol. Bull. mar. biol. Lab., Woods Hole 160: 292-302

Leder, J. J. III, Szmant, A. M., Swart, P. K. (in press). The effect of prolonged 'bleaching' on skeletal banding and stable isotopic composition in Montastrea annularis. Coral Reefs

Luna, L. G. (1968). Manual of histologic staining methods for the Armed Forces Institute of Pathology, 3rd edn. Blakiston Div., McGraw Hill Co., New York

Miller, R. L. (1985). Sperm chemo-orientation in the Metazoa. In: Metz, C. B., Monroy, A. (eds.) Biology of fertilization, Vol. 2. Academic Press, New York, p. 275-337
Porter, J. W. (1985). The maritime weather of Jamaica: its effect on annual carbon budgets of the massive reef-building coral Montastrea annularis. In: Gabrie, C. et al. (eds.) Proceedings of the Fifth International Coral Reef Congress, Tahiti, Vol. 6. Antenne Museum - EPHE, Moorea, French Polynesia, p. 363-379

Richmond, R. H., Hunter, C. L. (1990). Reproduction and recruitment of corals: comparison among the Caribbean, the tropical Pacific and the Red Sea. Mar Ecol. Prog. Ser. 60: 185-203

Rinkevich, B., Loya, Y. (1979). The reproduction of the Red Sea coral Stylophora pistillata. I. Gonads and planulae. Mar. Ecol. Prog. Ser. 1: 133-144

Rylaarsdam, K. W. (1983). Life histories and abundance patterns of colonial corals on Jamaican reefs. Mar. Ecol. Prog. Ser. 13: 249-260

Sebens, K. P. (1987a). Coelenterate energetics. In: Pandian, T. J., Vernberg, J. (eds.) Animal energetics. Academic Press, New York, p. 55-120

Sebens, K. P. (1987). The ecology of indeterminate growth in animals. A. Rev. Ecol. Syst. 18: 371-407

Soong, K. (1990). Reproduction of colonial reef corals: individuality of coral colonies and colony size-related characters. Ph.D. dissertation, University of Texas, Austin

Szmant, A. M. (1985). The effect of colony size on the reproductive ability of the Caribbean coral Montastrea annularis (Ellis and Solander). In: Gabrie, C. et al. (eds.) Proceedings of the Fifth International Coral Reef Congress, Tahiti, Vol. 4. Antenne Museum - EPHE, Moorea, French Polynesia, p. 295-300

Szmant, A. M. (1986). Reproductive ecology of Caribbean reef corals. Coral Reefs 5: 43-53

Szmant, A. M. Ferrer, L. M, FitzGerald, L. M. (1990). Nitrogen excretion and $\mathrm{O}: \mathrm{N}$ ratios in reef corals: evidence for conservation of nitrogen. Mar. Biol. 104: 119-127

Szmant-Froelich, A., Johnson, V., Hoehn, T., Battey, J., Smith, G. J., Fleischmann, E., Porter, J., Dallmeyer, D. (1981). The physiological effects of drilling muds on the Caribbean coral Montastrea annularis. In: Gomez, E. D. et al. (eds.) Proceedings of the Fourth International Coral Reef Symposium, Manila, Vol. 1. Marine Sciences Center, University of the Philippines, Quezon City, p. 163-168

Szmant-Froelich, A., Ruetter, M., Riggs, L. (1985). Sexual reproduction of Favia fragum (Esper): lunar patterns of gametogenesis, embryogenesis, and planulation in Puerto Rico. Bull. mar. Sci. 37: 880-892

Szmant-Froelich, A., Yevich, P., Pilson, M. E. Q. (1980). Gametogenesis and early development of the temperate coral Astrangia danae (Anthozoa: Scleractinia). Biol. Bull. mar. biol. Lab., Woods Hole 158: 257-269

Vaughn, T W. (1916). On the recent madreporaria of Florida, the Bahamas and the West Indies, and on collections from Murray Island, Australia, Yearb. Carnegie Instn Wash. 14: 220-231

Wellington, G. M., Glynn, P. W. (1983). Environmental influences on skeletal banding in eastern Pacific (Panama) corals. Coral Reefs 1: 215-222

Willis, B. L., Babcock, R. C., Harrison, P. L., Oliver, J. K., Wallace, C. C. (1985). Patterns in mass spawning of corals on the Great Barrier Reef from 1981 to 1984. In. Gabrie, C. et al. (eds.) Proceedings of the Fifth International Coral Reef Congress, Tahiti, Vol. 4. Antenne Museum - EPHE, Moorea, French Polynesia, p. 343-348

Wourms, J. P. (1987). Oogenesis. In: Giese, A. C., Pearse, J. S., Pearse, V B. (eds.) Reproduction of marine invertebrates, Vol. IX. Blackwell Scientific Publications, Palo Alto, California, p. $49-178$ 
Wyers, S. C. (1985). Sexual reproduction of the coral Diploria strigosa (Scleractinia, Faviidae) in Bermuda: research in progress. In: Gabrie, C. et al. (eds.) Proceedings of the Fifth International Coral Reef Congress, Tahiti, Vol. 4. Antenne Museum - EPHE, Moorea, French Polynesia, p. 301-306

Wyers, S. C., Barnes, H. S., Smith, S. R. (1991). Spawning of

This article was presented by R. S. Scheltema, Woods Hole, Massachusetts, USA hermatypic corals in Bermuda: a pilot study. Hydrobiologia (Symp. Vol. Ser.: 5th Internat. Conf. Coelenterate Biol. 1989) (in press)

Yevich, P., Barszcz, C. A. (1981). Preparation of aquatic animals for histopathological examination. United States Environmental Protection Agency, Narragansett Lab, (unpublished manual)

Manuscript first received: November 26, 1990 Revised version accepted: May 6, 1991 